\title{
Theory Acceptance Model and Purchase Intention in Online Shopping
}

\author{
Nova Adhitya Ananda \\ Department of Management \\ Sumbawa University of Technology \\ Sumbawa, Indonesia \\ nova.adhitya.ananda@uts.ac.id \\ Muhammad Nur Fietroh \\ Department of Management \\ Sumbawa University of Technology \\ Sumbawa, Indonesia \\ muhammad.nur.fietroh@uts.ac.id
}

\author{
Mikhratunnisa Mikhratunnisa* \\ Department of Agroindustrial Technology \\ Sumbawa University of Technology \\ Sumbawa, Indonesia \\ mikhratunnisa@uts.ac.id \\ Reza Muhammad Rizqi \\ Department of Management \\ Sumbawa University of Technology \\ Sumbawa, Indonesia \\ reza.muhammad.rizqi@uts.ac.id
}

\begin{abstract}
This study aims to analyze the effect of Theory Acceptance Model (TAM) on Purchase Intention. The analysis technique used in this study is the Structural Equation Model (SEM). With a total of 200 respondents. The results showed that the perceived ease of use influences customer's perceived usefulness, trust and purchase intention. Perceived usefulness influences customer's benefit and purchase intention. Benefits do not affect the purchase intention. A customer's trust influences customer's perceived usefulness and purchase intention. From the results of the sobel test it was also found that perceived usefulness and trust were mediating variables.
\end{abstract}

Keywords-Theory Acceptance Model (TAM), Purchase Intention and Structural Equation Modeling (SEM).

\section{INTRODUCTION}

In the era of globalization the need for an information is very important. Internet-based information systems are very widely used. In Indonesia, the development of the internet in recent years is quite fast. The Data from the Association of Internet Service Providers in Indonesia (APJII) reveals that internet users in Indonesia reached 171 million active users in 2018[1]. Where in the previous year internet users in Indonesia amounted to 143 million users.

Based on the results of a survey that conducted by APJII, it is also known that internet users most often use content from e-commerce to buy the goods via online. The increase volume of e-commerce users has a positive influence on the growth of Small and Medium Enterprises (SMEs) in Indonesia. Through e-commerce, sellers or SMEs can expand their distribution networks and markets. Then, this mutual relationship can increase sales from SMEs and ecommerce.

In 2018, Indonesia is the largest e-commerce market in Southeast Asia with a total transaction (Gross Merchandise Value) of US \$23.3 billion and is expected to increase in 2025 to US \$ 103 billion [2]. This indicates that e-commerce is a new way for Indonesian people to shop.

In addition to the positive effects on the growth of SMEs, consumer doubts about transacting in e-commerce still exist. This doubt arises as a result of fraud cases that have occurred during shopping, such as items that do not match with the photos in the application[3]. This trust issue arises as a result of consumers not being able to directly verify products purchased while shopping online compared to direct purchases. Especially in e-commerce, platforms usually mediate between seller and buyer. Consumer confidence is very important to increase consumer purchase intentions[4].

The problem in online shopping will be a resistor to the growth of e-commerce, because there are still doubts about consumers to make a purchase. The effectiveness of the use to e-commerce platforms can be seen from the emergence of purchase intentions. This study aims to determine the factors that can influence consumer purchase intentions on ecommerce platforms by examining one of the e-commerce platforms most frequently used by Indonesian consumers to shopping online, namely Shopee[1].

\section{THEORETICAL FRAMEWORK AND HYPOTHESIS}

\section{A. Theory Aceptance Model (TAM)}

Davis in 1998 first developed the Theory Acceptance Model (TAM) which is often used in measuring one's acceptance behavior towards new technology. TAM is used because it provides a powerful and simple explanation for technology acceptance. In addition, according to Chuttur, TAM is a very popular model and is often used by researchers to explain the use of technology[5]. Perceived ease to use and perceived usefulness are the main constructs of acceptance of new technology service users in the classic TAM model. Both constructs can reflect someones behavior towards the use of new technology, such as in e-commerce application platforms. The TAM davis model was later modified by Chuttur in 2009 .

Perceived ease of use is a belief in ease of use, it mean how strong the users confidence when using technology/system which can be used easily and free from problems. The ease of use of the system can also be seen from the intensity of the use and interaction from users with the system[6]. When the system / technology is easy to use, then the consumers will get benefits and useful information. This will increase their perceived usefulness[7]. So researchers hypothesize: 
H1 = Perceived ease of use influences customer's perceived usefulness.

In e-commerce, the fact that the more people use the ecommerce platform, the more people will conclude that online stores have a good reputation so this can increase the perception of consumer confidence in the platform. [7]

$\mathrm{H} 2$ = Perceived ease of use influences customer's trust

Perceived ease of use is able to reduce one's efforts to learn the system / technology because individuals believe that the system / technology is easy to understand. The more frequently the system / technology is used shows that the system is better known, easier to operate and easier to use so that makes them interested in making a purchase[8].

H3 = Perceived ease of use influences customer's purchase intention

Perceived usefulness is defined as the extent to which a system can improve the performance of its users [6]. In this study, we propose that the more consumers feel the benefits of online transactions made through e-commerce platforms, the greater the benefits they get compared to traditional purchases. Online transactions enable the consumers to make transactions faster than traditional transactions.

H4 = Perceived usefulness influences customer's benefit

Individuals who find it easier to use the internet will find it easier to benefit from the system. The perception of benefits has an influence on buying interest[9].

H5 = Perceived usefulness influences customer's purchase intention

Benefits are defined as the extent to which consumers benefit from online transactions. The intended benefits such as time savings and the number of types of products selected, this is not obtained if you buy in the traditional way[10]. When consumers feel the benefits of shopping online, they will be intent on making online transactions.

H6 = Benefit influences customer's purchase intention

Trust is built on the guarantee that online stores will fulfill all their obligations to consumers and care for consumers. In the e-commerce context, the vendor's responsibility is to provide useful information to consumers and facilitate consumers to complete the transaction process until the goods are received by consumers. Finally, consumers get perceived usefulness from their trust in e-commerce platforms[7].

$\mathrm{H} 7$ = A customer's trust influences customer's perceived usefulness

Trust plays an important role in online purchases because there is no face to face, so consumer confidence in sellers and e-commerce platforms becomes the main thing. When consumers already trust the platform, the consumer will make a purchase on that platform[11].

$\mathrm{H} 8=\mathrm{A}$ customer's trust influences customer's purhase intention

\section{B. Purchase Intention (PI)}

Ajzen in 1991 stated that intention is considered an indicator of the extent to which people want to approach certain behaviors and how much effort they are trying to do for carry out such behavior [12]. It must be recognized that the purchase intention cannot be interpreted as a purchase. In the future it is proposed to further investigate online purchase intention to have a significant influence on actual online purchases[13].

\section{METHODS}

\section{A. Population and sampling techniques.}

The population in this study are students of the Faculty of Economics and Business, Sumbawa University of Technology who use the Shopee application. The sampling technique uses purposive sampling with the criteria that the student uses the Shopee application in the last 3 months. The number of samples used in this study were 200 respondents.

\section{B. Data Analysis Techniques.}

The data analysis technique used in this research is Structural Equation Modeling (SEM). The testing step is[14]

1. Designing the inner model.

2. Designing the outer model.

3. Model evaluation.

4. Bootstraping resampling.

\section{FINDINGS}

\section{A. Data Analysis}

1. Designing the inner model produced as follows:

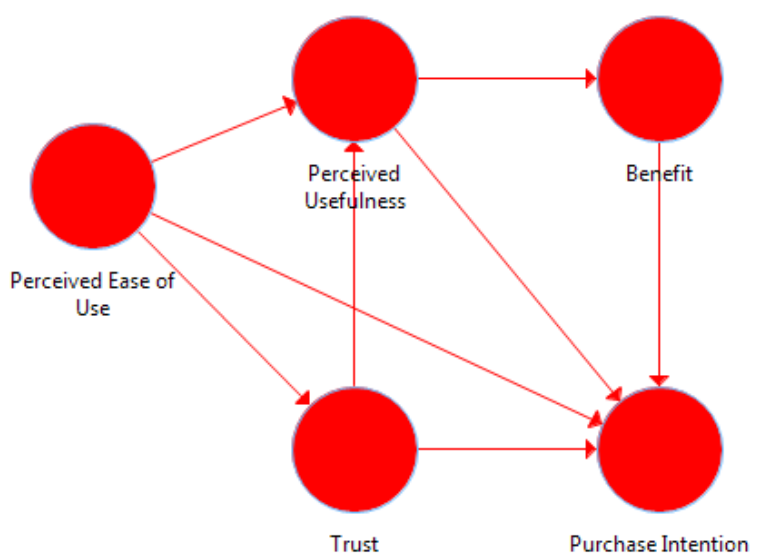

Fig.1. Designing the inner model

\section{Designing the outer model}

The indicator used in this study is a reflective indicator. Like in the picture below: 


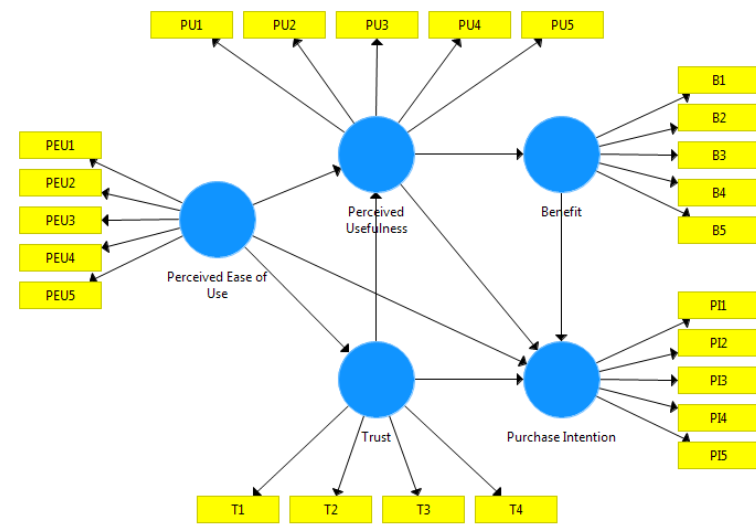

Fig.2. Designing the outer model

\section{Model evaluation}

a. Evaluation of outer models

Outer model is an assessment of the reliability and validity of research variables. The criterion size of a good reflective indicator is one that has a convergent validity correlation value of more than 0.70 . However, values from 0.5 to 0.6 can still be maintained for models that are still in the development stage[15].

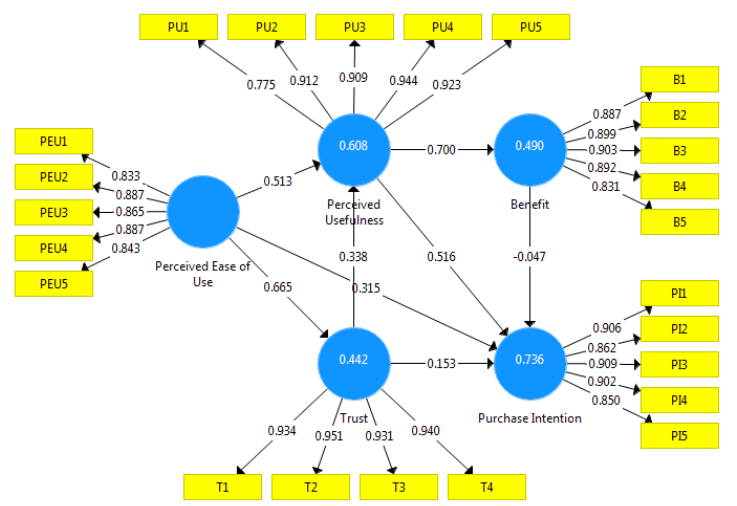

Fig.3. Outer loading output

The results of discrimating validity in the model can be seen in the value of crossloading as follows:

TABLE I. CRIMINAL VALIDITY

\begin{tabular}{|l|c|c|c|c|c|}
\hline \multirow{2}{*}{$\begin{array}{c}\text { Indicat } \\
\text { or }\end{array}$} & \multicolumn{5}{|c|}{ Construct } \\
\cline { 2 - 6 } B1 & 0.887 & 0.650 & 0.673 & 0.664 & 0.609 \\
\hline B2 & 0899 & 0.550 & 0.647 & 0.670 & 0.571 \\
\hline B3 & 0903 & 0.623 & 0.667 & 0714 & 0.626 \\
\hline B4 & 0.892 & 0.599 & 0.562 & 0704 & 0.540 \\
\hline B5 & 0831 & 0.557 & 0.517 & 0.640 & 0.480 \\
\hline PEU1 & 0.506 & 0833 & 0.605 & 0.493 & 0.609 \\
\hline PEU2 & 0.645 & 0.887 & 0.636 & 0.641 & 0.673 \\
\hline PEU3 & 0.586 & 0865 & 0.638 & 0.571 & 0.677 \\
\hline PEU4 & 0.527 & 0.887 & 0.604 & 0.535 & 0.652 \\
\hline
\end{tabular}

\begin{tabular}{|l|l|l|l|c|c|}
\hline \multirow{2}{*}{$\begin{array}{c}\text { Indicat } \\
\text { or }\end{array}$} & \multicolumn{5}{|c|}{ Construct } \\
\cline { 2 - 6 } & $\boldsymbol{B}$ & $\boldsymbol{P E U}$ & $\boldsymbol{P U}$ & $\boldsymbol{T}$ & $\boldsymbol{P I}$ \\
\hline PEU5 & 0.640 & 0843 & 0.692 & 0.615 & 0.683 \\
\hline PU1 & 0.527 & 0.638 & 0.775 & 0.434 & 0.583 \\
\hline PU2 & 0.623 & 0.666 & 0.912 & 0.658 & 0767 \\
\hline PU3 & 0706 & 0.673 & 0.909 & 0.664 & 0.787 \\
\hline PU4 & 0.628 & 0.642 & 0.944 & 0.629 & 0.758 \\
\hline PU5 & 0.634 & 0.683 & 0.923 & 0.624 & 0.748 \\
\hline Q1 & 0.721 & 0.603 & 0.624 & 0.934 & 0.626 \\
\hline Q2 & 0745 & 0.661 & 0.677 & 0.951 & 0.659 \\
\hline Q3 & 0745 & 0.625 & 0.636 & 0.931 & 0.639 \\
\hline Q4 & 0704 & 0.605 & 0.611 & 0.940 & 0.614 \\
\hline PI1 & 0.677 & 0.685 & 0818 & 0.626 & 0.906 \\
\hline PI2 & 0.525 & 0.632 & 0.648 & 0600 & 0862 \\
\hline PI3 & 0.544 & 0.674 & 0.783 & 0.580 & 0.909 \\
\hline PI4 & 0.567 & 0.673 & 0708 & 0.616 & 0.902 \\
\hline PI5 & 0.533 & 0725 & 0.655 & 0.576 & 0850 \\
\hline & & & & a. Research data processed
\end{tabular}

Based on the table above, it shows that indicators B1, $\mathrm{B} 2, \mathrm{~B} 3, \mathrm{~B} 4$, and B5 have a higher correlation to the Benefit construct (B) compared to the correlation to the construct of Perceived Ease to Use (PEU), Perceived Usefulness (PU), Trust (T) and Purchase Intention (PI). Likewise, the correlation of each other construct with indicators is higher than the correlation of indicators with other constructs.

Another method for measuring discriminant validity is by looking at the value of Average Variance Extracted (AVE). AVE value> 0.50 indicates that the construct in the study is declared valid[16].

TABLE II. AVERAGE VARIANCE EXTRACTED (AVE)

\begin{tabular}{|l|c|c|}
\hline \multicolumn{1}{|c|}{ Construct } & $\boldsymbol{A V E}$ & $\begin{array}{c}\boldsymbol{A V E} \text { status } \\
\boldsymbol{> 0 . 5 0}\end{array}$ \\
\hline Benefit (B) & 0.779 & Valid \\
\hline Perceived Ease to Use (PEU) & 0745 & Valid \\
\hline Perceived Usefulness (PU) & 0800 & Valid \\
\hline Trust (T) & 0.882 & Valid \\
\hline Purchase Intention (PI) & 0.785 & Valid \\
\hline
\end{tabular}

In addition to testing the construct validity, the construct reliability test also needs to be done by looking at the value of composite reliability and Cronbach's alpha. The data has good reliability if the composite reliability and Cronbach's alpha value is more than $0.70[14]$. The results are as follows:

TABLE III. RELIABILITY TEST

\begin{tabular}{|l|c|c|c|}
\hline \multicolumn{1}{|c|}{ Construct } & $\begin{array}{c}\text { Cronbach } \\
\text { Alpha }\end{array}$ & $\begin{array}{c}\text { Composite } \\
\text { Reliability }\end{array}$ & $\begin{array}{c}\text { Status } \\
\mathbf{> 0 . 7 0}\end{array}$ \\
\hline Benefit (B) & 0.929 & 0.946 & Reliable \\
\hline Perceived Ease to Use (PEU) & 0.914 & 0.936 & Reliable \\
\hline
\end{tabular}




\begin{tabular}{|l|c|c|c|}
\hline \multicolumn{1}{|c|}{ Construct } & $\begin{array}{c}\text { Cronbach } \\
\text { Alpha }\end{array}$ & $\begin{array}{c}\text { Composite } \\
\text { Reliability }\end{array}$ & $\begin{array}{c}\text { Status } \\
\mathbf{> 0 . 7 0}\end{array}$ \\
\hline Perceived Usefulness (PU) & 0.936 & 0.952 & Reliable \\
\hline Trust (T) & 0.955 & 0.968 & Reliable \\
\hline Purchase Intention (PI) & 0.931 & 0.948 & Reliable \\
\hline \multicolumn{4}{|c|}{${ }^{c} \cdot$ Research data processed }
\end{tabular}

b. Evaluate the inner model

Structural models that have R-Squre value> 0.67 are stated as good models, R-Square> 0.33 are moderate, and R-Square> 0.19 are considered weak[14].

TABLE IV. R-SQUARE

\begin{tabular}{|l|c|c|}
\hline \multicolumn{1}{|c|}{ Construct } & $\boldsymbol{R}$-Square & Status \\
\hline Benefit (B) & 0.488 & Moderate \\
\hline Perceived Ease to Use (PEU) & 0.604 & Moderate \\
\hline Trust (T) & 0.439 & Moderate \\
\hline Purchase Intention (PI) & 0.731 & Good \\
\hline \multicolumn{2}{|c|}{ d. Research data processed }
\end{tabular}

The relevance of predictions (Q-Square) which serves to validate the model. The results of Q-square predictive relevance can be stated well if the value> 0 provides evidence that the model has predictive relevance, while the $\mathrm{Q}$-Square value $<0$ indicates that the model lacks predictive relevance. The quantity Q2 has a value with a range of $0<\mathrm{Q} 2<1$, where the closer to 1 indicates the model the better. From table 4 above we can calculate Q-square predictive relevance for this research model, the results are as follows:

$$
\begin{aligned}
\mathrm{Q} 2 & =1-(1-\mathrm{R} 12)(1-\mathrm{R} 22)(1-\mathrm{R} 32)(1-\mathrm{R} 42) \\
& =1-(1-0.488)(1-0.604)(1-0.439)(1- \\
& =1-(0.512)(0.396)(0.561)(0.269) \\
& =1-0.031 \\
& =0.969(96.9 \%)
\end{aligned}
$$

\section{Bootstraping resampling}

\begin{tabular}{|c|c|c|c|}
\hline Construct & $\begin{array}{l}\text { Original } \\
\text { Sample }\end{array}$ & $\begin{array}{c}T \\
\text { Statistics }\end{array}$ & $\begin{array}{c}\text { Status } \\
\text { T Statistics> } \\
1,972\end{array}$ \\
\hline $\begin{array}{l}\text { Benefit }(B) \rightarrow \\
\text { Purchase Intention }\end{array}$ & $-0,047$ & 0.608 & $\begin{array}{c}\text { Not } \\
\text { Significance }\end{array}$ \\
\hline $\begin{array}{l}\text { Perceived Ease of Use (PEU) } \\
\overrightarrow{\text { Perceived Usefulness (PU) }}\end{array}$ & 0.513 & 8,546 & Significance \\
\hline $\begin{array}{l}\text { Perceived Ease of Use (PEU) } \\
\rightarrow \\
\text { Purchase Intention (PI) }\end{array}$ & 0.315 & 3,640 & Significance \\
\hline $\begin{array}{l}\text { Perceived Ease of Use (PEU) } \\
\rightarrow \\
\text { Trust (T) }\end{array}$ & 0.665 & 14,468 & Significance \\
\hline
\end{tabular}

The test statistic used is $\mathrm{t}$ statistic with $\mathrm{t}$ table value $($ significance $5 \%)=1.972$. The Research hypothesis is proven significant if the $\mathrm{t}$ value is statistically greater than 1.972 , it can be seen in the table below:

TABLE V. DIRECT EFFECT

\begin{tabular}{|l|c|c|c|}
\hline \multicolumn{1}{|c|}{ Construct } & $\begin{array}{c}\text { Original } \\
\text { Sample }\end{array}$ & $\begin{array}{c}\boldsymbol{T} \\
\text { Statistics }\end{array}$ & $\begin{array}{c}\text { Status } \\
\text { T Statistics }> \\
\mathbf{1 , 9 7 2}\end{array}$ \\
\hline $\begin{array}{l}\text { Benefit (B) } \rightarrow \\
\text { Purchase Intention }\end{array}$ & $-0,047$ & 0.608 & $\begin{array}{c}\text { Not } \\
\text { Significance }\end{array}$ \\
\hline $\begin{array}{l}\text { Perceived Usefulness (PU) } \rightarrow \\
\text { Benefit (B) }\end{array}$ & 0.700 & 13210 & Significance \\
\hline $\begin{array}{l}\text { Perceived Usefulness (PU) } \rightarrow \\
\text { Purchase Intention (PI) }\end{array}$ & 0.516 & 7,832 & Significance \\
\hline $\begin{array}{l}\text { Trust (T) } \rightarrow \\
\text { Perceived Usefulness (PU) }\end{array}$ & 0.338 & 5221 & Significance \\
\hline $\begin{array}{l}\text { Trust (T) } \rightarrow \\
\text { Purchase Intention (PI) }\end{array}$ & 0.153 & 2,361 & Significance \\
\hline & \multicolumn{3}{|c|}{ e. Research data processed } \\
\hline
\end{tabular}

From these data it can be concluded that H1, H2, H3, H4, $\mathrm{H} 5, \mathrm{H} 7$ and $\mathrm{H} 8$ were accepted while $\mathrm{H} 6$ was rejected. In this study apart from direct effects there are also indirect effects. To be able to find out the indirect effect, the sobel test is used. Here are the results:

TABLE VI. MEDIATING EFFECT

\begin{tabular}{|l|l|c|}
\hline \multicolumn{1}{|c|}{ Mediating } & \multicolumn{1}{|c|}{ Relationships } & $\begin{array}{c}\text { Sobel } \\
\text { Test }\end{array}$ \\
\hline Perceived Usefulness (PU) & $\begin{array}{l}\text { Perceived Ease of Use (PEU) } \\
\rightarrow\end{array}$ & 5769 \\
\hline Purchase Intention (PI) & $\begin{array}{l}\text { Perceived Ease of Use (PEU) } \\
\text { Trust (T) }\end{array}$ & 4,893 \\
\hline Trust (T) & $\begin{array}{l}\text { Perceived Usefulness (PU) } \\
\text { Perceived Ease of Use (PEU) } \\
\text { Purchase Intention (PI) }\end{array}$ & 2,323 \\
\hline Benefit (B) & $\begin{array}{l}\text { Perceived Usefulness (PU) } \rightarrow \\
\text { Purchase Intention (PI) }\end{array}$ & $-0,609$ \\
\hline
\end{tabular}

${ }^{\mathrm{f} .}$ Research data processed

From the calculation of the sobel test above it gets $\mathrm{z}$ value> 1,960 with a significance level of $5 \%$, it can be said that 1) Perceived Usefulness (PU) is a mediating variable of the relationship between Perceived Ease of Use (PEU) on Purchase Intention (PI). 2) Trust (T) is a mediating variable of the relationship between Perceived Ease of Use (PEU) and Perceived Usefulness (PU). 3) Perceived Ease of Use (PEU) against Purchase Intention (PI) is mediated by Trust (T). And 4) The effect of Perceived Usefulness (PU) on Purchase Intention (PI) cannot be mediated by the Benefit (B) variable.

\section{CONCLUSION}

This study aims to analyze the purchase intention of Shopee e-commerce platform users at the Faculty of Economics and Business, Sumbawa University of Technology. Data obtained from 200 respondents who have ages between 15-25 years. The results showed that Purchase intention was directly affected by Perceived ease of use, Perceived usefulness and trust.

In this study, the object that was examined was only limited to the Shopee platform. For further research to compare research variables for different e-commerce platforms in Indonesia.

\section{REFERENCES}

APJII, "Report on the Survey of Penetration and Behavior of Indonesian Internet Users," 2018. 
[2] Katadata, "Infographics: Indonesia's Largest E-Commerce Market in Southeast Asia," Aug-2019.

[3] Tiara Ningrum Dirum, "The Effect of Consumer Confidence on Online Buying Interest," 2019.

[4] K. Kwahk, X. Ge, and J. Park, "Investigating the Determinants of Purchase Intention in C2C E-Commerce," Int. J. Soc. Behav Educ. Econ. The bus. Ind. Eng., vol. 6, no. 9, pp. 497-501, 2012.

[5] M. Chuttur, "Overview of the Technology Acceptance Model: Origins, Developments and Future Directions," Sprout, vol. 9, no. 2009, pp. 9-37, 2009

[6] FD Davis, "Perceived Usefulness, Perceived Ease of Use, and User Acceptance of Information Technology," MIS Q., vol. 13, no. 3, pp. 319-340, May 1989.

[7] M.-Y. Chen and C.-I. Teng, "A comprehensive model of the effects of online store image on purchase intention in an ecommerce environment,"Electron. Commer. Res., vol. 13, no. 1, pp. $1-23,2013$.

[8] SD Sitorus and MK Mawardi, "The Effect of Perception on Ease, Risk Perception, and Consumer Confidence on Online Purchase Interests," J. Adm. and business, vol. 73, no. 1, pp. 141-150, 2019.
Model," Int. J. Electron. Commer., vol. 7, no. 3, pp. 101-134, Apr. 2003.

[10] L. Magherio, The Emerging Digital Economy. Washington DC: US Department of Commerce, 1998.

[11] AA Kholis and PN Madiawati, "The Influence of Site Security, Trust On Purchase Intention On Shopee Online Shopping Site," e-Proceeding Manag., vol. 6, no. 2, pp. 4299-4306, 2019.

[12] I. Ajzen, "The theory of planned behavior," Organ. Behav Hum Decis. Process, vol. 50, no. 2, pp. 179-211, Dec. 1991.

[13] NA Jamil and NKN Mat, "To Investigate The Drivers Of Online Purchasing Behavior In Malaysia Based On Theory Of Planned Behavior (TPB): A Structural Equation Modeling (SEM) Approach," in International conference on management (ICM 2011) proceeding, 2011, pp. 453-460.

[14] I. Ghozali, Structural Equation Modeling Alternative Methods with Partial Least Square (PLS). Semarang: Diponegoro University, 2014

[15] WW Chin, The Partial Least Square Approach to Strutural Equation Modeling. London: Mahwah, New Jersey, 1998.

[16] K. Gana and G. Broc, Structural Equation Modeling with Lavaan. Hoboken: John Willey \& Sons, Inc., 2019. 